\title{
The PSOE's deliberation and democratic innovations in turbulent times for the social democracy
}

\author{
Oscar Barberà $^{1}$ (D) . Juan Rodríguez-Teruel ${ }^{1}$ [D
}

(C) European Consortium for Political Research 2019

\begin{abstract}
In the midst of the great recession, the Spanish Socialists Worker's Party (PSOE) lost the Government and experienced a process of instability while trying to reconnect with its electorate. The party's strategic response was embracing highly inclusive deliberations on both key institutional and policy issues that eventually sparked tensions and division. These internal debates led to the introduction and implementation of other democratic innovations, such as direct votes and consultations that substantially transformed key features of the PSOE's organizational model. The article discusses the main features and problems of such deliberations and democratic innovations, and their wider consequences.
\end{abstract}

Keywords Deliberation $\cdot$ Political parties $\cdot$ Spain $\cdot$ Social democracy

\section{Introduction}

Social Democracy in Southern European countries faced hard choices after the financial and economic crisis of the late 2000s. Yet, not all parties shared the same fortune. In this context, the Spanish Socialists Worker's Party (PSOE, in Spanish) might be taken as a successful case study of how a combination of scaling-up deliberation and democratic innovations contributed to address its organizational challenges, to reshape the party brand and, in the long run, to reverse its electoral misfortunes. However, this was not an uncontroversial adaptation. As the Demos' case study in this volume also shows (Gherghina and Stoiciu EPS2019), implementing party reforms in such a harsh political and socio-economic environment become quite a contested process that produced intra-party conflicts and transformed the internal power balance.

Oscar Barberà

o.barbera@uv.es

Juan Rodríguez-Teruel

jrteruel@uv.es

1 University of Valencia, Av. Tarongers s/n, Valencia, Spain 
The PSOE was formed in the late XIX century as a typical mass party but reemerged in the 1970s as catch all organisation under Felipe González's leadership. González centralised and modernised its organisation, while adapting it to Spain's emerging multi-level setting. A generous public funding regime and the party's long tenure in government (1982-1996) favoured the predominance of the public office over the extra-parliamentary face (Gunther 1986; Share 1988; Van Biezen 2003). However, by the 1990s the PSOE's organizational strength diminished due to its break-up with the socialist trade union, several political scandals and the growing quarrels between two main factions trying to control González's succession (Méndez 2000; Royo 2000). After losing the government, the party introduced limited reforms (party primaries) but most of its organizational features and factionalism remained the same. The main change was the emergence of some regional party leaders and prime ministers as key players in the party's internal decision-making process. Their role was instrumental in José Luis Rodríguez-Zapatero's selection as party leader and through his time in opposition (Méndez 2006). Rodríguez-Zapatero's opposition strategy was quite successful in leading the PSOE to the government, but he mostly focused on renewing the old party elite, proposing new policies and mobilising its party members than introducing organizational reforms (Méndez 2006; Encarnación 2009).

After two terms in government, by 2011 the PSOE got its worst results since 1977. Rodríguez-Zapatero's government was blamed for the poor handling of the crisis and the implementation of harsh austerity policies. Indeed, the social and political consequences of the Great Recession led to low levels of trust in Spain's main institutions, to declining party identifications and to a new wave of protests epitomised by the Indignados movement that started in May 2011 in the streets of Madrid and later on extended to all Spain. However, by the early 2010s Spain also faced relevant tensions linked to other political divides such as both mainstream parties' adversary politics (crispación) and the centre-periphery cleavage that significantly contributed to a growing dissatisfaction with parties and institutions (Kennedy 2012; Bosco 2018, chap. 1 and 3). The end of the PSOE's government was also marked by the return of factional disputes and the growing power of the regional party leaders. In this context, by 2011 and 2012 the party executive faced strong pressures from either the party membership or would-be party leaders to introduce organizational reforms and to change the party strategy. The PSOE's main representative decisionmaking agencies first partially contained the introduction of party primaries, but a lengthy and complex deliberation process led to key changes in the party organisation and strategy. Shortly afterwards, the 2015 and 2016 electoral deadlock opened a new internal debate on the party strategy that was strongly intertwined with the politics of the party leadership and other organizational issues. This second deliberation process openly confronted the strategy and organizational model of the PSOE's main representative bodies and party elites with the ones of the new party leader, Pedro Sánchez, and most of the party membership. Sánchez's unexpected victory in the 2017 primaries led to a second wave of democratic innovations and to a change to the former party strategy (Delgado-Fernández and Cazorla-Martín 2017; Bosco 2018, chap. 4; Correa, Barberà and Rodríguez-Teruel 2018). Some months later, that strongly contributed to the formation of a new socialist government. The following 
section will present the main characteristics of such transformations, while the next one will shortly assess their main institutional and policy consequences.

\section{A break with the past: general features and problems of the PSOE's deliberations}

The comparative literature and the introduction of this symposium have extensively analysed political parties' response strategies to re-encapsulate a more volatile and eventually shrinking membership and electoral base (Gherghina, Soare and Jacquet EPS2019). The bulk of such organizational changes were based on vote-centric democratic innovations such as party primaries for candidates and party leaders and membership ballots for policy development (Cross and Katz 2013; Scarrow 2014; Sandri et al. 2015). Far less attention has been paid to deliberative practices such as the ones implemented by the Czech, Romanian and Danish parties discussed in this volume (Vodova and Voda ECPS2019; Gad EPS2019; Gherguina and Stoiciu, EPS2019). Such empirical case studies are in line with a new turn in the deliberative theory suggesting the potential role of political parties as key facilitators of linkage among citizens and political elites through new conceptions of talk-centric intraparty democracy (Teorell 1999; Rosenblum 2008; Invernizzi-Accetti and Wolkenstein 2017). In this vein, Wolkenstein and his colleagues have suggested that parties might be understood as a complex arrangement of multiple deliberative fora and institutions forming a whole deliberative system (Wolkenstein 2016, p. 6; Ebeling and Wolkenstein 2018). That said, most of this literature tends to focus on deliberation at the local level or on local party branches because there seems to be easier to fulfil some of the classical requirements of equality, diversity or rationality suggested by many deliberative theorists (e.g. Wolkenstein 2016, pp. 11-13, 2018, pp. 3-7). Moving away from the local perspective, this section explores the context, main features and problems of the two most important debates held within the PSOE during its last time in the opposition. Its main point is to provide further evidences of how such deliberative systems might work in practice at the national level.

\section{Expanding party primaries (2011-2014)}

Most Spanish parties favoured leadership and candidate selection processes through representative party agencies or congresses with delegates since the late 1970s. That said, the party leadership enjoyed a paramount relevance in these processes, eventually in cooperation with the regional elites. Limited reforms were eventually introduced in the late 1990s, such as the PSOE's closed primaries to select top candidates in particular circumstances, but none of the mainstream parties substantially changed their procedures till the early 2010s (Barberà et al. 2015; Ramiro 2016). Between 2011 and 2014, the PSOE tried to break up with this tradition through the introduction of more inclusive selection methods (Table 1). The debate was first opened when Prime Minister Rodríguez-Zapatero withdrew from being candidate in the upcoming 2011 general elections. Two ministers from the cabinet (Carme 
Table 1 PSOE's main debates and democratic innovations (2011-2017). Source: Authors' own

\begin{tabular}{lll}
\hline Promoter & Internal debates & Main results \\
\hline Contender and minority factions & Party primaries (2011) & No election (1 candidate) \\
Contender and minority factions & Party strategy (2012) & No shift \\
& Party primaries (2012) & Change of party statues \\
Party leader \& Regional elites & Territorial policy (2013) & Policy Shift \\
Contenders & Party strategy (2014) & Strategy shift \\
& Party primaries (2014) & 1st party leadership primary \\
& & Change of party statutes \\
Party leader & Coalition behaviour (2016) & 1st consultation (PSOE \& Cs deal) \\
Party leader & Coalition behaviour (2016) & Strategy shift \\
Party Council \& Regional elites & & No party congress (and primaries) \\
Interim Committee & Party Strategy and organization & Strategy and organizational shift \\
& (2017) & 2nd party leadership primaries \\
& Party primaries (2017) & \\
\hline
\end{tabular}

Chacón and Alfredo Pérez-Rubalcaba) emerged as contenders, which automatically would have led to party primaries. However, Chacón finally retired her candidature and there were no membership ballots. Pérez-Rubalcaba became the top candidate and right after the 2011 results; he also claimed the party leadership. That reopened the dispute with Chacón, and the internal debate on the selection of candidates and party leaders through primaries. ${ }^{1}$ The 2012 leadership contest was finally decided in a congress with delegates won by Pérez-Rubalcaba by a very slim margin. That congress also allowed to select the future national and regional top candidates (not the leaders) by members and supporters. That congress started an informal and bottom up deliberative process in which emerged new demands for more inclusiveness. During several weeks, academics, commentators, groups of party members and even by some minority factions and regional elites made statements to the press or posted comments online on such issues. The exchange of arguments was highly rational (pros vs. cons) although it was connected to the politics of party leadership. It was also quite inclusive because expanded well beyond the party elites. At the same, there were recognisable differences in the influence of the different proposals. Interestingly, it ended up with the party finally overcoming its reluctances and embracing party primaries. In 2013, the PSOE's central office tolerated the election of Galicia's regional party leader through a closed primary for the first time. After the $2014 \mathrm{EU}$ elections, Pérez-Rubalcaba's resignation paved the way to implement a similar procedure to select the new party leader, Pedro Sánchez. He then reformed the party statutes and tried to redefine the PSOE's policies through a new reformist appeal in order to compete with two emerging parties, Podemos and Ciudadanos (Fundación Alternativas 2015, chap. 5; Bosco 2018, chap. 3; Correa et al. 2018).

\footnotetext{
${ }^{1}$ Chacón suggested the introduction of open primaries to select the PSOE's candidates (El País 2011). Some of Chacón's supporters and other minority factions also claimed for party leadership primaries.
} 


\section{Disagreements on the PSOE's coalition behaviour and organizational model (2015-2017)}

The 2015-2016 electoral deadlock distressed the Spanish politics. Despite the electoral results, Pedro Sánchez's tried to strengthen his position as the PSOE's party leader and to redefine the party strategy, which confronted him with some of his former allies. Facing a growing internal opposition, Sánchez's tried to promote plebiscitary innovations (i.e. direct votes) in order to legitimise his leadership. He did so through two initiatives. First, he conducted for the first time ever an internal referendum to support the PSOE and Ciudadanos' agreement favouring Sánchez's investiture as prime minister. The internal consultation took place on February 2016 during 3 days through the miPSOE online platform and voting boxes in the local branches. Around $50 \%$ of the party members voted on that event and almost $80 \%$ of them did it in favour of the agreement. The innovation was considered a big success, and in the 2017 party congress the PSOE modified its statues to implement binding consultations for all future national and regional government agreements (and to allow internal referenda on other key decisions) (El País 2017). The second move has become much more controversial. Sánchez contested the 2016 general elections promising to veto a PP investiture ('No es no'). The party accepted his stance during the campaign, but after the election it came under growing pressure for the PP was actively seeking the PSOE's abstention and blaming them for a possible third general election. In addition, a regional party leader insinuated that he was willing to challenge Sánchez's leadership, which led to a growing number of party elites slowly positioning themselves against the veto.

That opened up a new informal deliberation that lasted for months. In a way, that was highly inclusive because several media outlets, some regional prime ministers, all former party leaders, the different factions and the party membership exchanged views on what to do in several fora inside and outside the party organisation. However, not all opinions were equally considered which might rise doubts on this requirement. Moreover, at some point even party unity seemed at stake which led to heated and emotional controversies. The rationality was also undermined because the party board and the press interpreted some of the comments as an open challenge to the party leadership. And yet, over time the party changed its position over these issues. Sánchez's response consisted in intertwining the coalition behaviour and the leadership puzzles with the legitimacy of intra-party democracy. Hence, in order to avoid being challenged and being able to keep his veto, he tried to call for a new party congress which would also imply organising party primaries. At the end, he resigned as party leader and parliamentarian when the PSOE's main representative party agency blocked his plans for that congress. That pointed out questions on the authority of the party leadership and on the legitimacy of representative institutions controlled by the party elites vis-à-vis the will of the party membership. Sánchez's risky move proved to be right and, some months after an interim period, Sánchez won the primaries for the leadership. Shortly afterwards, a party congress reinforced party leadership's powers and undermined the authority of the main representative bodies through the introduction of membership ballots (Bosco 2018, chap. 4). 
Table 2 Party activists' support to intra-party democracy. Source: Own data, from a survey to the party delegates to the PSOE 38 and 39 Congresses (held in 2012 and 2017, respectively). Data show proportion of individuals scoring 4 and 5 in a scale 1 (low importance) to 5 (high importance)

\begin{tabular}{llr}
\hline & 2012 & 2017 \\
\hline $\begin{array}{l}\text { The more important decisions in a political party must be taken directly by the grass- } \\
\text { roots members }\end{array}$ & 60.4 & 65.9 \\
\begin{tabular}{l} 
The leader and the candidates should be directly elected by the grassroots members \\
\hline
\end{tabular} & 73.6 & 82.9 \\
\hline
\end{tabular}

\section{Assessing the electoral and organisational consequences}

As the previous section has shown, the PSOE's time in opposition was deeply marked by two complex and informal deliberations. As a result, the party ended up changing its original responses and developing new democratic innovations for policy development, such as party primaries and direct votes. In this respect, the PSOE's also resembles the Danish Alternativet or the Romanian Demos in their quest for new forms of intra-party democracy (Gad EPS2019; Gherguina and Stoiciu, EPS2019). The electoral consequences of such internal debates and organizational changes have been unclear, though. After the first deliberation process, Pedro Sánchez achieved the worst results ever in the two general elections (2015 and 2016). On the contrary, the second internal deliberation not only improved the party showing at the polls, but allowed the PSOE to return to the government after unexpectedly winning a no-confidence vote. Once back in the executive, the party won the 2019 early election with almost 30 per cent of the votes and the highest number of absolute votes in 10 years. Nevertheless, this victory was less a direct effect of the successive primary votes than the product of its short stay in power and Podemos' swift electoral decline. The electoral recovery also extended to the European, regional and local elections in May 2019.

The organisational consequences have been far more clear, as they contributed to strengthen the power of the party leader and to reinforce the disintermediation process to the detriment of the party middle-level elites (Biancalana 2018). In this respect, the PSOE followed the path of many cartel parties trying to react to weakening linkages with its electoral base (Katz and Mair 1995; Biancalana 2018). At the party on the ground, the two internal deliberations and the adoption of party primaries and membership consultations have also allowed a higher say of party members on key internal decisions. In turn, that has increased the legitimacy and support for such mechanisms among the party grassroots. As seen in Table 2, a majority of the party activists already supported a stronger direct participation of the party members before their introduction. Interestingly, that support was reinforced 5 years later despite the conflicts generated by their introduction and implementation (see previous section). On the other hand, the internal tensions certainly did not help to expand the party membership, as the party lost the 5\% of its members between 2014 and 2017.

Another of the most outstanding consequences of the internal debates and the strengthening of direct votes has been the eroding power of the regional leaders. 
This was particularly relevant between 2014 and 2017 for most of the internal conflicts of this period. The second informal deliberation process had also to do with the struggle between the party leader and the regional leaders to control the PSOE's decision-making system. As stated in previous sections, the latter were instrumental in 2014 Sánchez's victory, but during the 2015-2016 electoral deadlock, their differences over the veto to the PP investiture lead to a certain clash of legitimacies. While Sánchez claimed that the ultimate decision should rest on the party membership and the party statues had to change, the regional party leaders benefited from the status quo represented by the party statutes and their control of the main representative bodies. Sánchez return to power after the 2017 primaries confirmed the disintermediation trend: he was less consensual in selecting the party executive and fostered organisational reforms to limit the power of the main representative party agencies through compulsory membership ballots for the party's key decisions (government agreements, etc.). This plebiscitary turn also strengthened the role of the national executive to the detriment of the regional bodies' autonomy. Overall, this also meant that the PSOE's main deliberative fora were undermined.

Interestingly, most of such reforms have been defended with a populistic rhetoric against 'the party elites', usually identified with these territorial elites. In this respect, Sánchez leadership has often used an intensive populistic message to sustain the division between him and his internal opponents, referring sometimes to those 'powerful enemies', including also economical and media actors outside the party. $^{2}$ This discourse was also combined with an overwhelmingly personalistic style in his performance and decisions, unparalleled with previous leaders in the party (Rodríguez-Teruel 2019). Such discourses and style eventually ended up eroding the rationality of the second deliberative process.

The empowerment of the party leader has also been reflected in the party at the institutions. On the one hand, the central office strengthened its control over the parliamentary party at the national parliament. This was particularly evident when Sánchez came back to the leadership after the 2017 primary election. Despite not having a parliamentary seat, he could reshuffle PSOE's parliamentary group appointing an independent MP as a new chief. Until the end of that term, the parliamentary strategy remained subordinated to the party leadership, adopting a secondary role in order not to overshadow him. Some months later, the candidate selection processes for the following general election produced an unprecedented removal of those MPs that had been openly critical with the leader. On the other hand, when Sánchez finally became prime minister, he benefited from the personal authority and the party power cumulated in his hands. Despite his parliamentary minority (just $24 \%$ of the chamber), he enjoyed extended freedom to form a government with few

\footnotetext{
${ }^{2}$ Few days after his resignation in October 2016, Sánchez declared in a TV interview in prime time that he had been victim of a complot launched by internal party elites and other outer interests aiming to block a leftwing coalition government with Podemos ("Salvados", La Sexta channel, 30 October 2016). Two years later in his book 'Handbook of resistance', Sánchez also referred to that incident arguing that the PSOE suffered from lack of democracy and leadership (Sánchez 2019, p. 38).
} 
parliamentary ministers, many of them non-affiliated to the PSOE, and to design an executive with high concentration of powers around the premiership.

\section{Lessons learned and conclusions}

The Spanish case, as the Danish Alternativet or the Romanian Domos, illustrates that embracing deliberation and promoting intra-party democracy alone may not be sufficient to (re)connect a party with its electoral base. The PSOE case study shows how the long deliberation process over the party primaries and its 2014 implementation could not reverse an adverse electoral trend. Conversely, a combination of democratic reforms and important strategic shifts like the ones derived from the 2015-2017 internal deliberation process might help regain legitimacy, starting to reconnect with the voters and, eventually, profit from favourable contextual factors (the fortune or actions of other parties). That was indeed the case with the PSOE's successful vote of no confidence in 2017.

The PSOE case also shows how its informal deliberation processes ended up strengthening the role of membership ballots and other plebiscitary forms of intraparty democracy. To some extent, this has more to do with the critical juncture and internal division in the party than with the uses of deliberation. Direct voting and plebiscitary remedies emerged in the first deliberation as a way to challenge the power of a weak party leader (Rubalcaba). They resulted in the second deliberation as a way to strengthen Sánchez's emerging leadership. As a result, the main outcomes were the centralisation of power within the party, the personalisation of the leader, and the disintermediation of the internal dynamics to the detriment of the intermediate party agents. The authority and control of the party leader eroded the power of the factions, of the regional party leaders and, more broadly, of all the party middle-level elites. Indeed, many critics saw in that strategy a 'Podemos-style' turns in order to successfully compete with the new radical left. It is debatable to what extent such organisational changes led to the empowerment or disempowerment of the party grassroots. On the one hand, the party leadership and the party central office have probably become more responsive towards the membership demands. On the other one, deliberative fora and institutions were undermined.

Finally, this case study aimed to point out that parties might indeed develop large deliberative processes, as has been suggested by the normative theory (Wolkenstein 2016; Ebeling and Wolkenstein 2018). Future research should focus on other comparative case studies in order to provide more empirical evidences of how and under which circumstances such processes are being implemented.

\section{References}

Barberà, O., M. Lisi, and J. Rodríguez-Teruel. 2015. Democratising Party Leadership Selection in Spain and Portugal. In Party Primaries in Comparative Perspective, ed. G. Sandri, A. Seddone, and F. Venturino, 59-84. Farnham: Ashgate.

Biancalana, C. 2018. Disintermediazione e nuove forme di mediazione. Verso una democrazia post-rappresentativa?. Milano: Feltrinelli.

Bosco, A. 2018. Le quattro crisi della Spagna. Bologna: Il Mulino. 
Correa, P., O. Barberà, and J. Rodríguez-Teruel. 2018. El PSOE y la impotencia de la izquierda. In Las elecciones generales de 2015-2016, ed. F.J. Llera, M. Baras, and J. Montabes, 183-205. Madrid: Centro de Investigaciones Sociológicas.

Cross, W.P., and R.S. Katz. 2013. The Challenges of Intra-Party Democracy. Oxford: Oxford Univeristy Press.

Delgado-Fernández, S., and Á. Cazorla-Martín. 2017. El partido socialista obrero español: De la hegemonía a la decadencia. Revista Espanola de Ciencia Politica 1(44): 247-273.

Ebeling, M., and F. Wolkenstein. 2018. Exercising Deliberative Agency in Deliberative Systems. Political Studies 66(3): 635-650.

El País. 2011. 'Chacón quiere que simpatizantes y militantes elijan al candidato del PSOE'. 28 December. Available at: https://elpais.com/politica/2011/12/28/actualidad/1325107542_786320.html.

El País. 2017. 'La consulta a las bases sobre acuerdos de Gobierno será obligatoria'. 17 June. Available at: https://elpais.com/politica/2017/06/17/actualidad/1497715841_951508.html.

Encarnación, O.G. 2009. Spain's New Left Turn: Society Driven or Party Instigated? South European Society and Politics 14(4): 399-415.

Fundación Alternativas. 2015. Informe sobre la democracia en España. 2015. Madrid: Fundación Alternativas.

Gunther, R. 1986. The Spanish Socialist Party: From Clandestine Opposition to Party Government. In The Politics of Democratic Spain, ed. S. Payne, 8-47. Chicago: Chicago Council on Foreign Relations.

Invernizzi-Accetti, C., and F. Wolkenstein. 2017. The Crisis of Party Democracy, Cognitive Mobilization, and the Case for Making Parties More Deliberative. American Political Science Review 111(1): 97-109.

Katz, R.S., and P. Mair. 1995. Changing Models of Party Organization and Party Democracy: The Emergence of the Cartel Party. Party Politics 1(1): 5-28.

Kennedy, P. 2012. From Unpopular Socialists to the Popular Party: The Spanish General Election of 2011. West European Politics 35(3): 673-681.

Méndez, M. 2000. La estrategia organizativa del Partido Socialista Obrero Espanol (1975-1996). Madrid: Centro de Investigaciones Sociológicas.

Méndez, M. 2006. Turning the Page: Crisis and Transformation of the Spanish Socialist Party. South European Society and Politics 11(3-4): 419-437.

Ramiro, L. 2016. Effects of Party Primaries on Electoral Performance. Party Politics 22(1): 125-136.

Rodríguez-Teruel, J. 2019. ‘¿Dejadme solo, que yo me basto!', Agenda Pública 13 February. Available at: http://agendapublica.elpais.com/dejadme-solo-que-yo-me-basto/.

Rosenblum, N.L. 2008. On the Side of the Angels. An Appreaciation of Parties and Partisanship. Princeton and Oxford: Princetion University Press.

Royo, S. 2000. From Social Democracy to Neoliberalism. The Consequences of Party Hegemony in Spain, 1982-1996. New York: St. Martin's Press.

Sánchez, P. 2019. Manual de resistencia. Madrid: Península.

Sandri, G., A. Seddone, and F. Venturino. 2015. Party Primaries in Comparative Perspective. Farnham: Ashgate.

Scarrow, S.E. 2014. Beyond Party Members: Changing Approaches to Partisan Mobilization. Oxford: Oxford University Press.

Share, D. 1988. Dilemmas of Social Democracy in the 1980s: The Spanish Socialist Workers Party in Comparative Perspective. Comparative Political Studies 21(3): 408-435.

Teorell, J. 1999. A Deliberative Defence of Intra-Party Democracy. Party Politics 5(3): 363-382.

Van Biezen, I. 2003. Political Parties in New Democracies. Basingstoke and New York: Palgrave Macmillan. Wolkenstein, F. 2016. A Deliberative Model of Intra-Party Democracy. Journal of Political Philosophy 24(3): 297-320.

Wolkenstein, F. 2018. Intra-Party Democracy Beyond Aggregation. Party Politics 24(4): 323-334.

Publisher's Note Springer Nature remains neutral with regard to jurisdictional claims in published maps and institutional affiliations.

Oscar Barberà is associate professor at the Universitat de València (UV). His main areas of interest are party politics, decentralization and political elites. His latest contributions are in Comparative European Politics, Zeitschrift für Vergleichende Politikwissenschaft, Revista de Estudios Políticos and several edited volumes from the Spanish Centro de Investigaciones Sociológicas. 
Juan Rodríguez-Teruel is Associate Professor at the University of Valencia. He has also been lecturer at the Autonomous University of Barcelona and visiting fellow at the universities LSE, Edinburgh, Leiden, ULB and Nottingham. His main areas of research are political elites and party politics. He is author of Ministers in Democratic Spain (Linz Award 2007, in Spanish). His work has been published in South European Politics and Society, Ethnic and Racial Studies, Comparative European Politics, Acta Politica or Contemporary Sociology. 